Tectonophysics, 25 (1975) 115-137

(C) Elsevier Scientific Publishing Company, Amsterdam - Printed in The Netherlands

\title{
PALAEOMAGNETISM OF UPPER PERMIAN RED BEDS IN THE WARDHA VALLEY, CENTRAL INDIA*
}

\author{
C.T. KLOOTWIJK** \\ Palaeomagnetic Laboratory, State University of Utrecht, Utrecht (The Netherlands)
}

(Submitted May 15, 1973; revised version accepted for publication July 1, 1974)

\section{ABSTRACT}

Klootwijk, C.T., 1975. Palaeomagnetism of Upper Permian red beds in the Wardha Valley, Central India. Tectonophysics, 25: 115-137.

For a detailed palaeomagnetic research on Upper Permian red beds in the W'ardha Valley (Central India) 265 samples from 47 sites at 6 localities were investigated.

The samples from 3 localities ( 17 sites) appeared to be completely remagnetized during Early Tertiary times by the vast Deccan Trap flood basalts effusions. The samples from 22 sites of the other three localities (results from 8 sites rejected) could become cleaned from hard secondary Deccan Trap components by detailed thermal demagnetization.

The resulting primary magnetization component reveals a mean direction (regardless of polarity, 7 sites normal, 15 sites reversed ): $D=101.5^{\circ}, I=+58.5^{\circ}, \alpha_{95}=6.5^{\circ}, N=3$. This mean direction corresponds to a pole position at $129^{\circ} \mathrm{W} 4^{\circ} \mathrm{N}\left(d p=7^{\circ}, d m=9.5^{\circ}\right)$. This pole position fits well with other acceptable Late Permian-Early Triassic pole positions for the Indian subcontinent. From these acceptable results, a mean Permo-Triassic pole for the Indian subcontinent was computed at: $125^{\circ} \mathrm{W} 6^{\circ} \mathrm{N}$. This Indian Permo-Triassic pole position, when compared with data from other Gondwanaland continents, suggests the hypothesis of an early movement between India and $\Lambda$ frica before Permo-Triassic times.

The partial or total remagnetization of some Indian red beds, mainly of Gondwana age, during Deccan Trap times is explained as acquisition of viscous Partial Thermoremanent Magnetization. This mechanism was advanced by Briden (1965), Chamalaun (1964) and Irving and Opdyke (1965).

\section{INTRODUCTION}

The disruption of Gondwanaland probably started in the area of the present Western Indian Ocean. The timing of the break up, however, cannot be deduced uniquely from the very complex seafloor-spreading data. A comparison between coeval palaeomagnetic data from the Gondwanaland continents concerned may give necessary additional information. However, some of the Lower

\footnotetext{
* This paper forms part of a doctoral thesis.

** At present: Department of Geology and Mineralogy, State University of Utrecht, Oude Gracht 320, Utrecht.
} 
Gondwana data from the Indian subcontinent published upto this time are presumably not suitable for such a study (Klootwijk, 1974a) owing to the probably incomplete elimination of secondary magnetization components. These secondary components were acquired during the Deccan Trap Period (dated at 60-65 m.y., Wellmann and McElhinny, 1970; Kaneoka and Haramura, 1973), when vast masses of tholeiitic flood basalts spread out over Western and Central India. Thermal cleaning is a prerequisite to eliminate these hard "Deccan Trap" components.

As part of a program to study the palaeomagnetic data of Gondwana material (Late Carboniferous to Late Cretaceous in age) from the Indian subcontinent (Klootwijk, 1971; Wensink, 1973b; Klootwijk, 1974a), an extensive collection of samples was taken from Upper Permian red beds in the Wardha Valley (Central India). These samples were subjected to detailed thermal cleaning.

\section{GEOLOGICAL SETTING}

The Wardha area is situated at the northern extremity of the Wardha-Pranhita-Godavary Valley, a NNW-SSE stretching graben in the Indian shield. Directly to the west of this Wardha area, remnants of a former Deccan Trap cover are found (Fig. 1). Compact argillaceous sandstones of a deep red to purple colour and red argillaceous shales, both of Lower Gondwana age, are found in this Wardha area. These red beds have been divided into the Upper Permian Kamthi beds (type locality sampled in the present study), and the slightly younger Mangli beds (type locality sampled by Wensink, 1968). However, in the field a distinction between the Mangli beds and the upper part of the Kamthi beds is difficult. The compact argillaceous shales and sandstones of a deep red to purple colour, which form a specific sequence in the higher part of the Kamthi formation, strongly resemble the typical Mangli beds. This difficult lithological distinction between the Mangli and the Kamthi beds caused some ambiguities. For instance, the Mangli beds at the type locality have been originally mapped as Kamthis (Hughes, 1877, p. 71 ), and the red beds directly south of Wun $\left(79^{\circ} 1^{\prime} \mathrm{E} 20^{\circ} 3^{\prime} \mathrm{N}\right)$ quoted as Kamthis by Wensink (1968), have been described in fact as equivalent to the Mangli beds (Hughes, 1877 , p. 75; Pascoe, 1959, p. 1062). The age of this whole red-bed sequence might reach from a Late Permian- (Kamthi beds) up into an Early Triassic age (Mangli beds). A Late Permian age seems most acceptable, because recent palynological data from the Panchet beds (NE India), which are correlated with the Mangli beds from the Wardha Valley, can be interpreted in terms of a Late Permian instead of an Early Triassic age (H. Visscher, personal communication, 1972; Klootwijk, 1974a). Therefore, the sampled red beds concerned are grouped together as Upper Permian in the present study. 


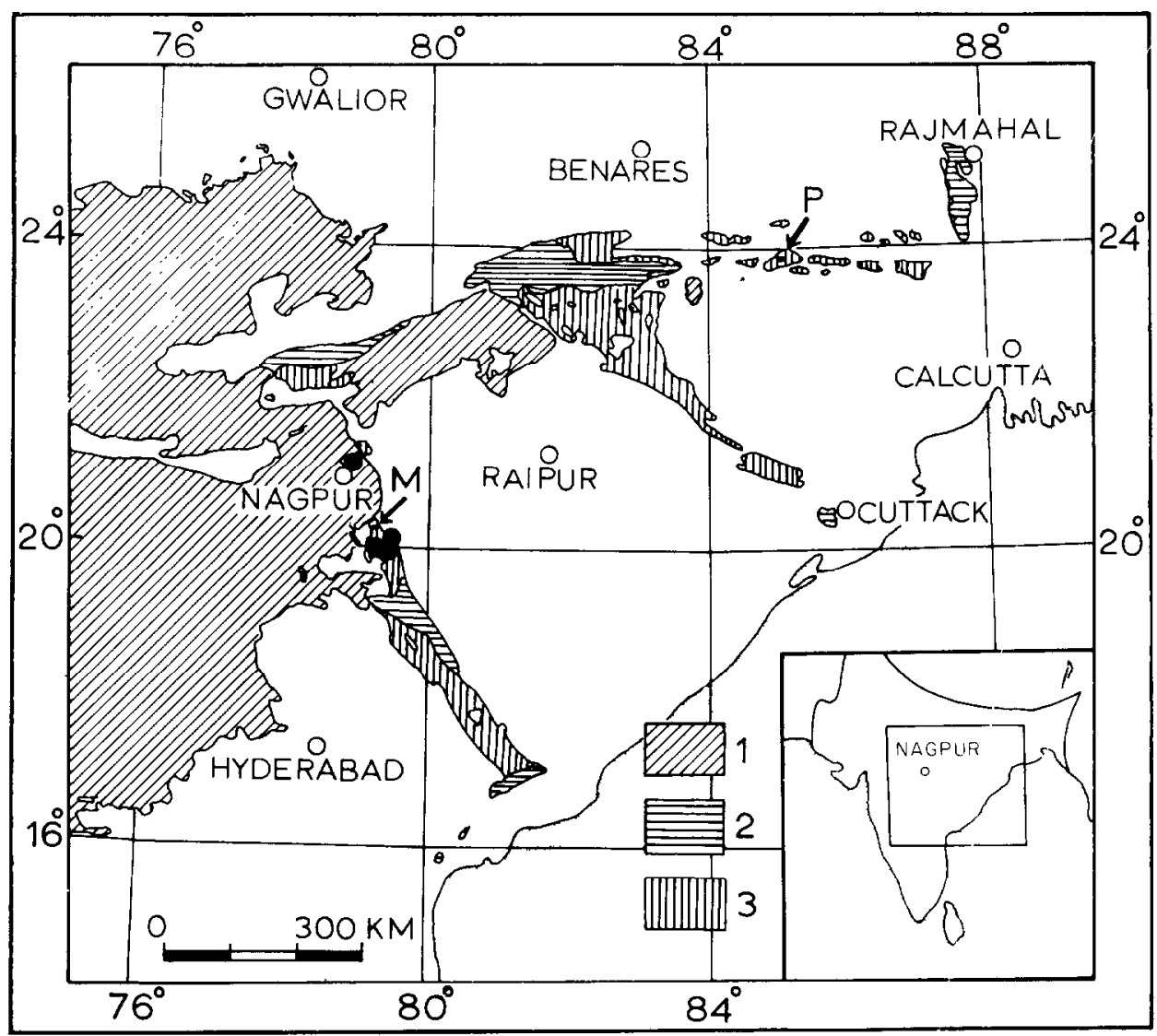

Fig. 1. Geological sketchmap of Gondwana outcrops in Eastern and Central India. $1=$ Deccan Traps, $2=$ Upper Gondwana outcrops, 3 = Lower Gondwana outcrops, $M=$ sampling locality Mangli beds, Wensink (1968), $P$ = Sampling locality Panchet beds, Klootwijk (1974a). Unshaded : basement and Cenozoic deposits. Dots: sampling localities, present study.

\section{SAMPLING DETAILS AND LABORATORY TREATMENT}

Core samples were obtained by means of a portable drill in the six localities (Fig. 1) mentioned in Table I. In some localities, handsamples were taken as well. At each of the 47 sites, usually at least six samples were taken*. Orientation of the samples was performed with a normal compass and a clinometer.

Altogether 389 specimens, $2.5 \mathrm{~cm}$ diameter and $2.2 \mathrm{~cm}$ height, were obtain-

\footnotetext{
* In this paper: site denotes a specific layer or sometimes a specific zone in an outcrop area (locality).
} 


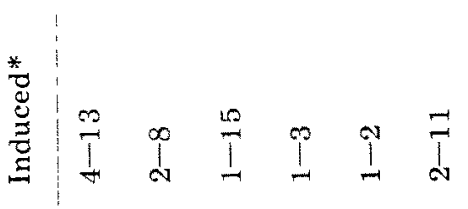

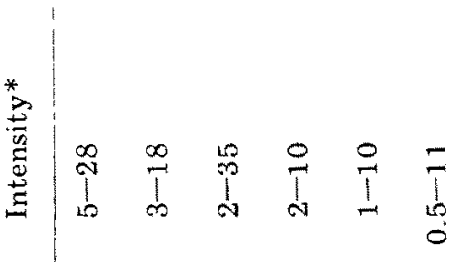

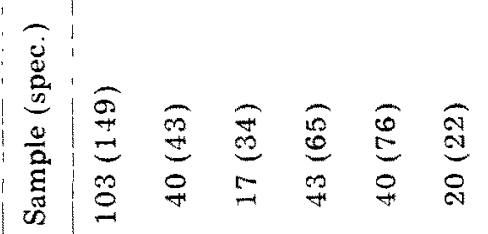

8

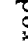

齐

$\stackrel{7}{=}$

है

$\stackrel{9}{ \pm}$

$\Xi$

番

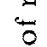

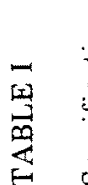$$
\text { : }
$$$$
i_{\infty}
$$

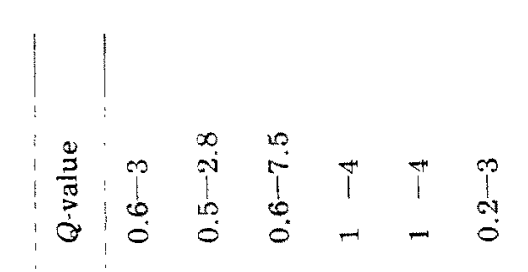

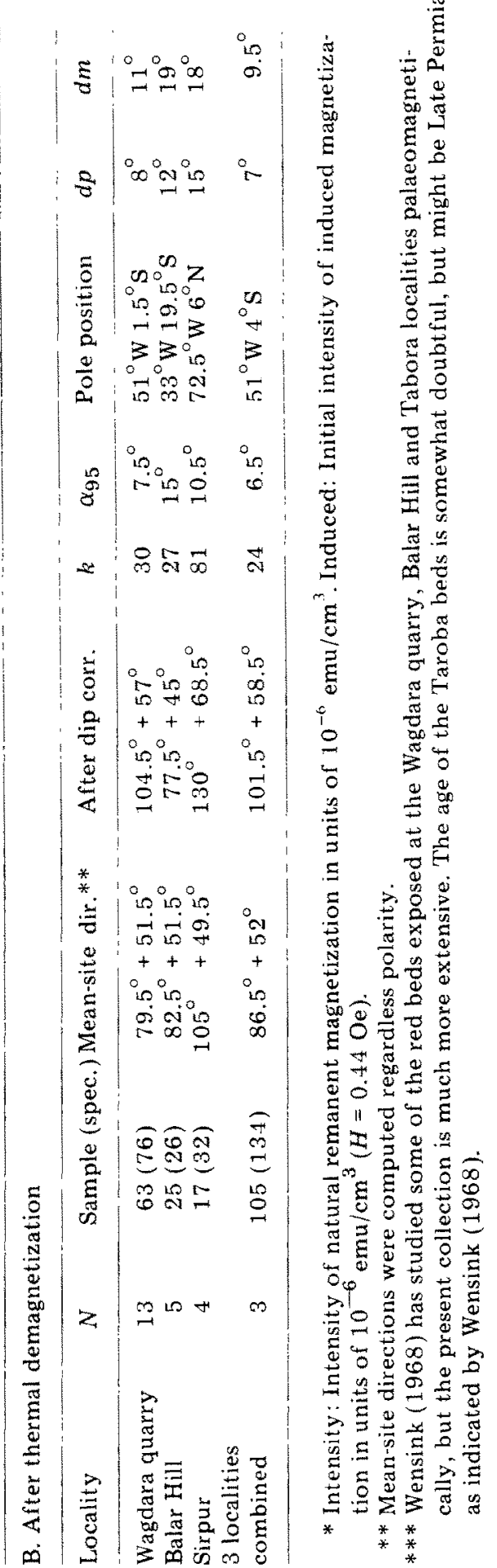


ed from the cores and the handsamples. From each site at least one pilot specimen was subjected to progressive thermal demagnetization up to $700^{\circ} \mathrm{C}$, or to alternating-fields treatment up to 3000 Oe peak value. Extensive care was taken to eliminate hard secondary magnetization components, thermal treatment above $550^{\circ} \mathrm{C}$ proved to be most suitable.

The oven used in the thermal-demagnetization studies has been built and described by Mulder (1971). A field-free space in the oven is created by three sets of square Helmholtz coils. Each pair of coils is powered by a current source with a stability better than $0.01 \%$. At the beginning of the heating experiment, field-nulling is adjusted with an accuracy of about $1 \gamma$ by means of a commercial fluxgate-gradiometer. This means that slight disturbances of zero-field are mainly due to fluctuations of the earth's magnetic fjeld. Occasionally such fluctuations might reach values around $25 \gamma$, but most often these fluctuations are much smaller during the - several hours - timespan of the heating experiment.

The rocks were heated in steps to progressively higher temperatures and cooled down to room temperature after each heating step. In order to avoid possible oxidation of the rock samples, the heating and cooling were done in argon gas. After cooling the intensity and direction of the remaining magnetization was measured.

All measurements were carried out on sensitive astatic magnetometers. The directional analysis was made according to Zijderveld (1967) and Klootwijk $(1971,1973)$ by means of computer plots of orthogonal projection figures which reveal the behaviour of the total magnetization vector upon demagnetization treatment for each specimen separately.

\section{RESULTS}

\section{Wagdara quarry}

From the northern limb of an E-W stretching syncline, altogether 103 samples ( 17 sites) were collected from red argillaceous and sandy shales. The beds hal a SSW dip of about $20^{\circ}$.

The initial measurements revealed rather well concentrated northward directions with both upward and to a lesser extent downward inclinations (Figs. 2A, 4B). The initial directions approach more towards the mean Deccan Trap direction, extrapolated for the Wardha Valley area according to the central axial dipole field formulae $\left(D=338^{\circ}, I=-51^{\circ}\right.$, Athavale et al., 1970; Wensink and Klootwijk, 1971; Pal and Bhimasankaram, 1973; Wensink, 1973a; Klootwijk, 1974b), than towards the present local field direction (Fig. 2A: $D=358^{\circ}, I=+27^{\circ}$ ).

Fifteen pilot specimens were subjected to progressive thermal demagnetization up to $685^{\circ} \mathrm{C}$. In general three magnetic components could be distinguished in these specimens. A recent local field component present in some samples was removed at temperatures below $350^{\circ} \mathrm{C}$. In most samples another 

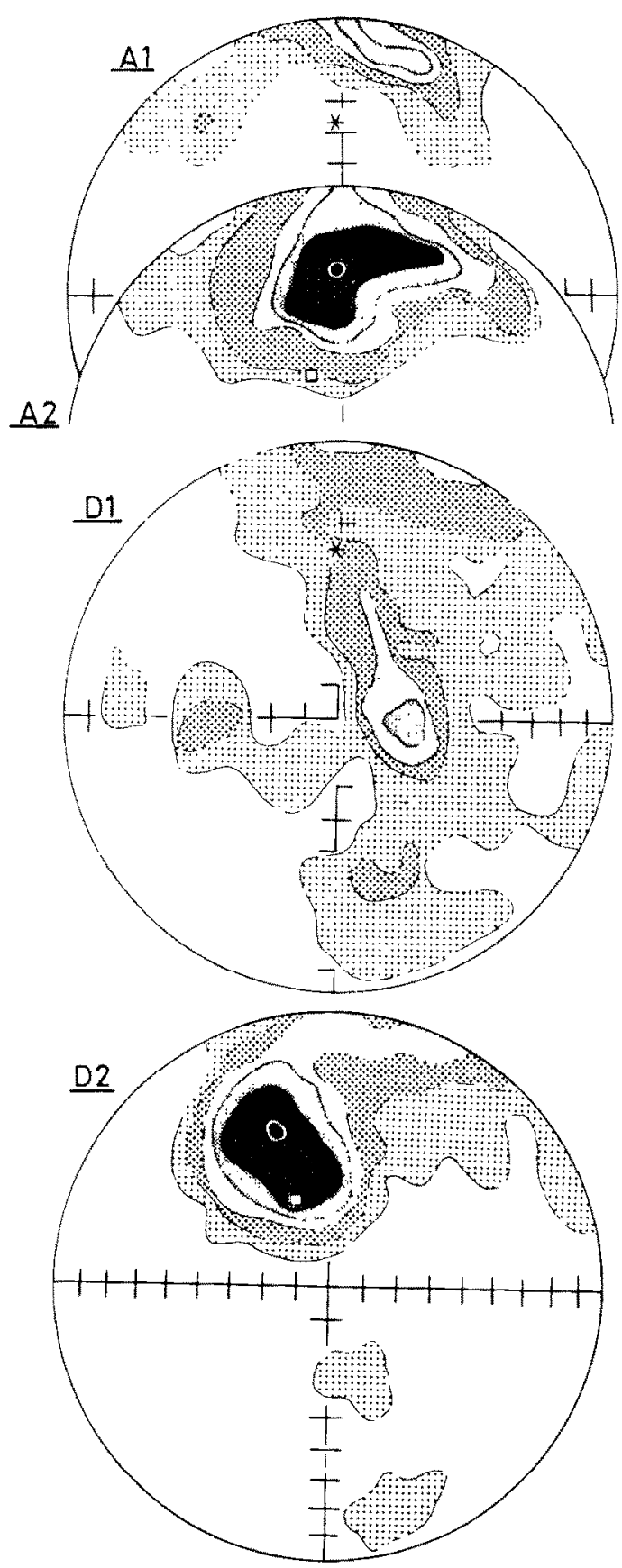
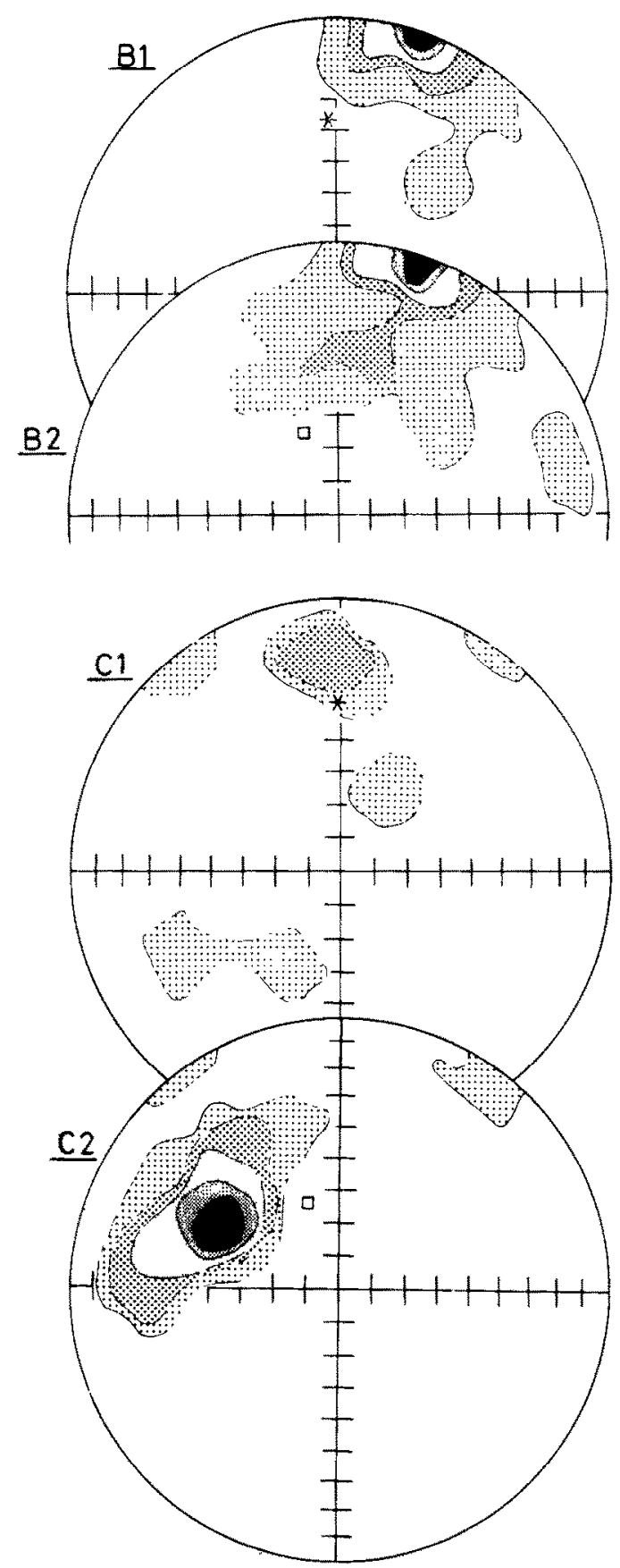

Fig. 2. Density distribution of Natural Remanent Magnetization directions in equal-area projection. Subscript 1 denotes lower-hemisphere projection, subscript 2 denotes upperhemisphere projection. Square denotes the normal Deccan Trap direction, pointing upwards. Asterisk denotes the present local field direction at the sampling area, pointing downwards. A. Wagdara quarry specimens. B. Balar Hill specimens. C. Sirpur specimens. D. Silewara, Chanda and Taroba specimens together. 

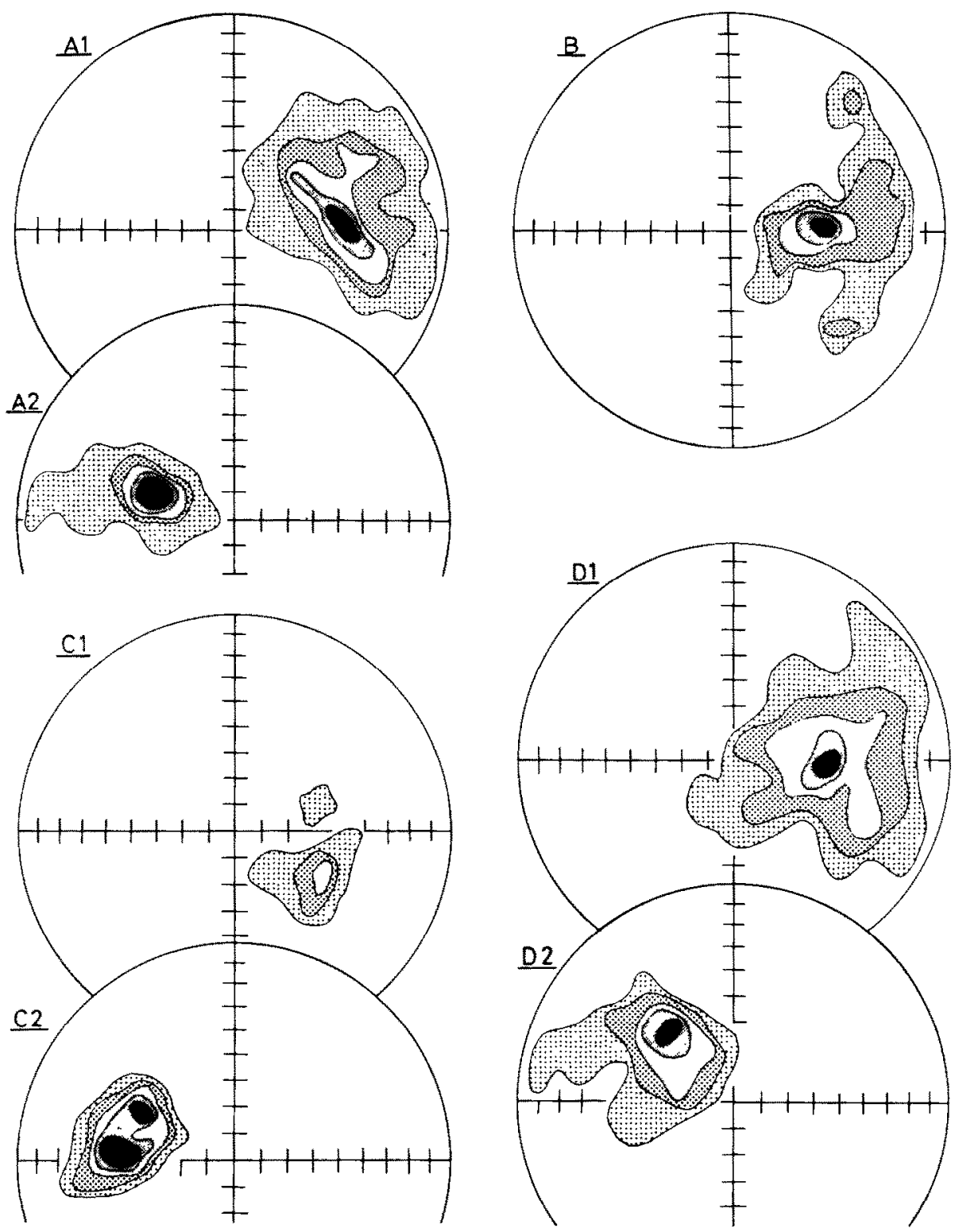

Fig. 3. Density distribution of characteristic directions, obtained after thermal treatment. Equal-area projection. Characteristic directions from eight aberrant sites, which were rejected for the mean-site direction computation, are included. Explanation as under caption to Fig. 2. A. Wagdara quarry specimens, before dip correction. B. Balar Hill specimens, before dip correction. C. Sirpur specimens, before dip correction. D. Wagdara quarry, Balar IIill and Sirpur specimens together, after dip correction. 
component, directed NNW and upwards, representing 50-90\% of the initial intensity, was eliminated completely at about $550^{\circ} \mathrm{C}$ (Figs. 5, 9A). The latter secondary component is more or less aligned according to the Deccan Trap direction (Fig. 10A).

In practically all specimens a third and obviously single component of normal or reversed polarity was removed between $550^{\circ}$ and $680^{\circ} \mathrm{C}$. This third component was thought to be of primary origin. Therefore, from the remaining specimens, another 84 were chosen for partial progressive thermal treatment in 10-12 steps between $550^{\circ}$ and $680^{\circ} \mathrm{C}$. From 13 sites the directions otained for the third component concentrate fairly well in reversed and normal groups (Fig. 3A). The mean-site direction from these 13 sites (Fig. 11) is: $D=104.5^{\circ}, I=+57^{\circ}$ (dip correction applied). In most samples from the other four sites, the direction of the third component could not be determined accurately. A detailed analysis of the behaviour of the total magnetization vector upon demagnetization treatment between $550^{\circ}$ and $680^{\circ} \mathrm{C}$ by means of orthogonal projection figures, revealed either that the end-points of the total magnetization vector were widely scattered, or that a secondary Deccan Traplike component, not yet fully eliminated in some samples around $550^{\circ} \mathrm{C}$, was removed simultaneously with the third (primary) component of low intensity. Therefore, these four sites are discarded.

\section{Balar Hill}

At Balar Hill, a'sout $4 \mathrm{~km}$ ESE of the Wagdara quarry, the synclinal closure of the here westward plunging syncline is exposed. Silicified beds and chalcedoneous material, found at the topographical high Balar Hill itself, indicate a former Deccan Trap cover. About half a kilometer WSW of this hill, on the southern limb of the syncline, 42 cores ( 9 sites) were drilled from red argillaceous shales dipping $5^{-} 8^{\circ}$ in NNE direction.

Initial intensities of magnetization in these specimens were similar to the intensities from the correlated Wagdara quarry samples (Table I). The initial directions showed a NNE trend with low both upward and downward inclinations (Figs. 2B, 4B). The Balar Hill specimens show a less pronounced streaking towards the Deccan Trap direction.

During progressive thermal demagnetization of 6 pilot specimens (Fig. 6), a NNW to NNE and upwards directed component, representing $70-85 \%$ of the initial intensity (Fig. 9B), became eliminated at peak temperatures between $500^{\circ}$ and $550^{\circ} \mathrm{C}$. This component clearly shows a Deccan Trap tendency, although some of the samples showed a NNE instead of a NNW trend (Fig. 10A). The remaining component, eastwards and downwards directed and thought to be of primary origin, was removed between $550^{\circ}$ and $680^{\circ} \mathrm{C}$. Therefore, the remaining 36 specimens were partially progressively treated in ten steps between these temperatures. All obtained directions belonged to the reversed group (Fig. 3B). Upon analysis of the orthogonal projection figures, several samples from 4 sites revealed the same aberrant behaviour 
Еัّ (1)

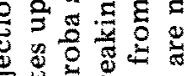
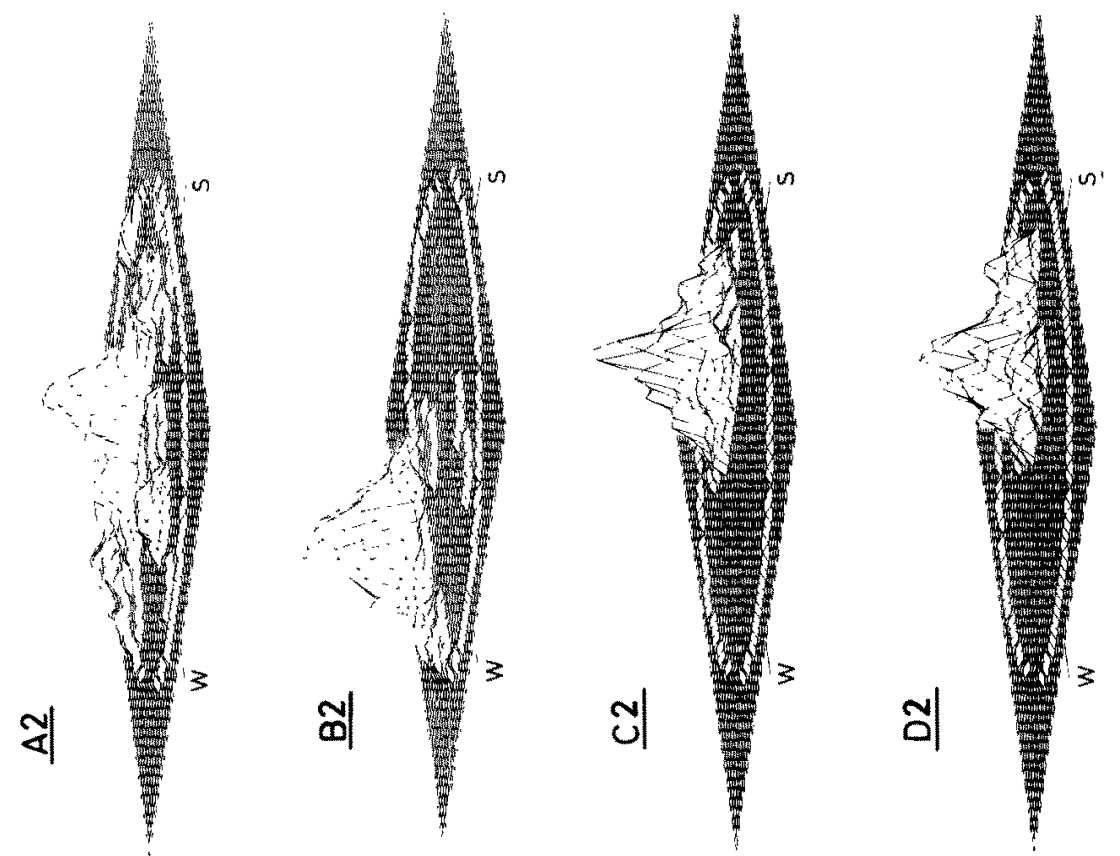

范范气

웡

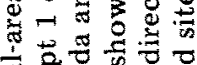
政的. I

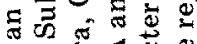

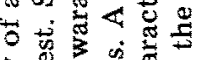
$3 \stackrel{0}{=}$ 号的任。 ๑ 亏

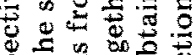
ङ

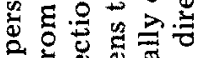

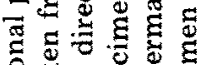

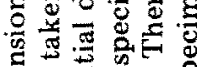

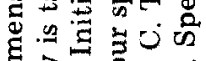

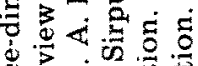

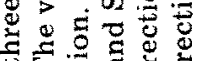

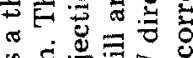
* ฐ
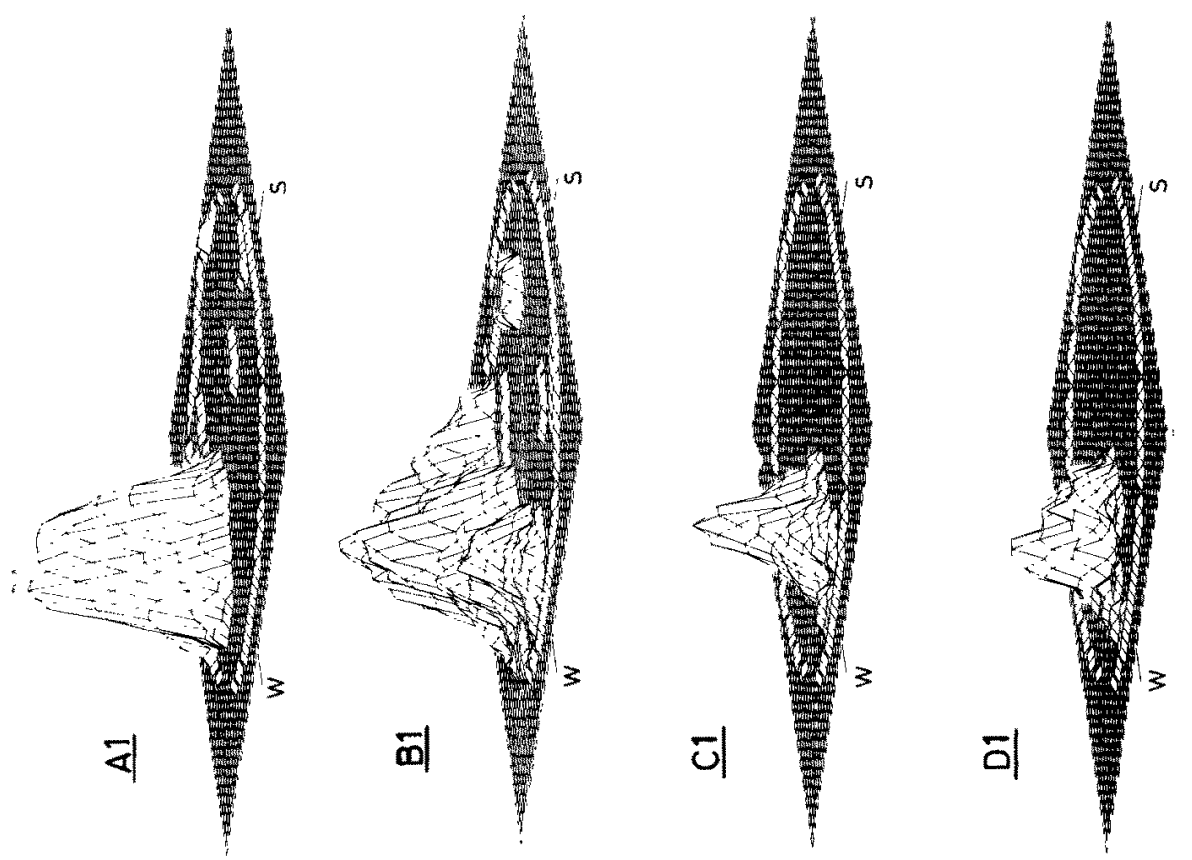

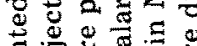
次跑

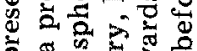

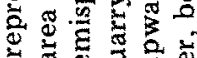
늘

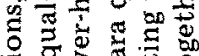

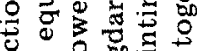

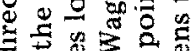

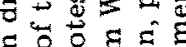
5 О छ

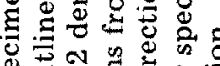

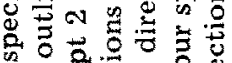

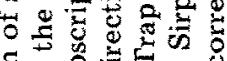

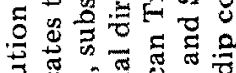

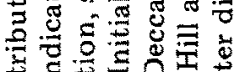

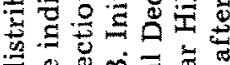
ป。

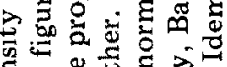

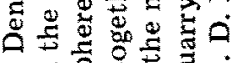
نे

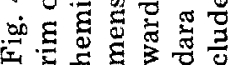



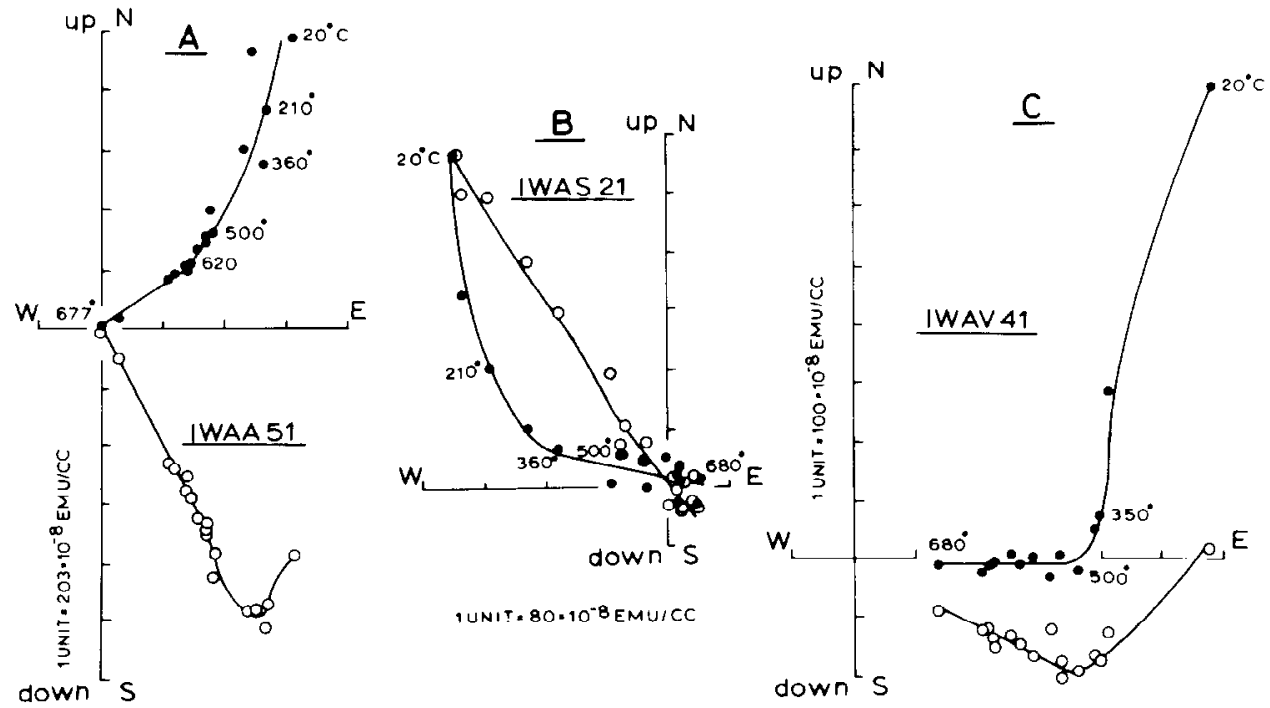

Fig. 5. Demagnetization diagrams of thermally treated Wagdara quarry specimens. The points represent successive positions - in orthogonal projection - of the end of the resultant magnetization vector during progressive demagnetization. Circles denote projections on the vertical east-west plane. Dots denote projections on the horizontal plane. Numbers denote successive peak values of the applied temperatures.
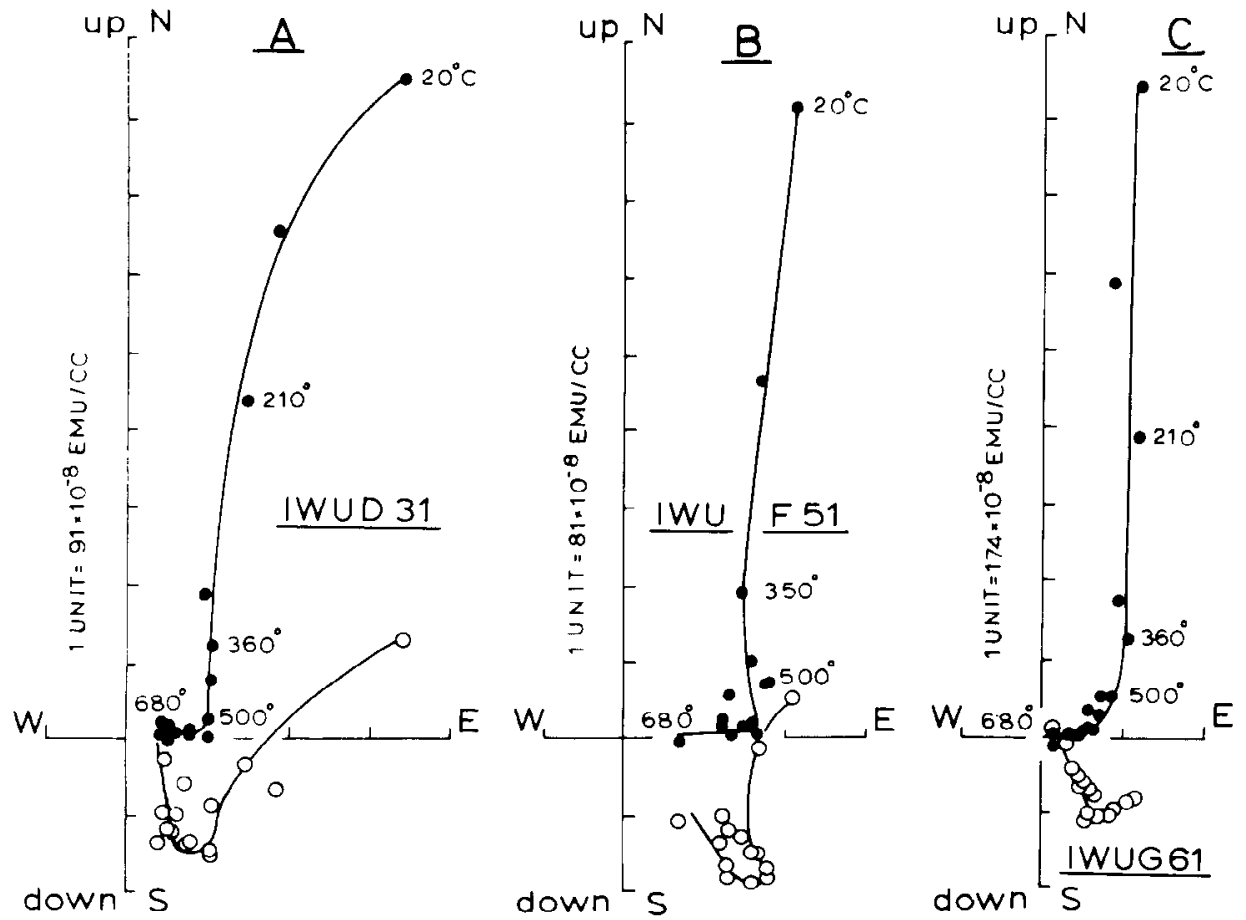

Fig. 6. Demagnetization diagrams of thermally treated Balar Hill specimens. See caption to Fig. 5. 

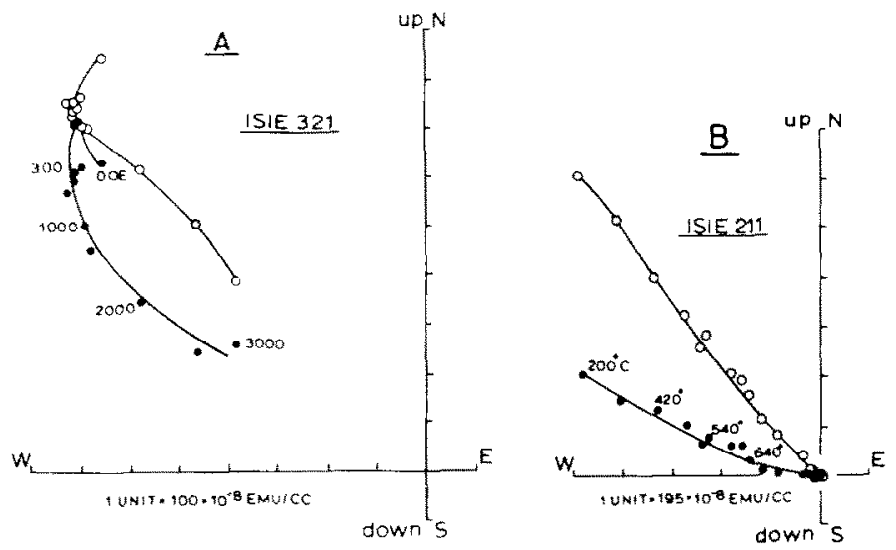

Fig. 7. Demagnetization diagrams of Sirpur specimens, treated with alternating fields (A) or by thermal methods (B). Numbers denote Oe-peak values of the applied alternating fields (A), or successive peak values of the applied temperatures (B). See caption to Fig. 5.
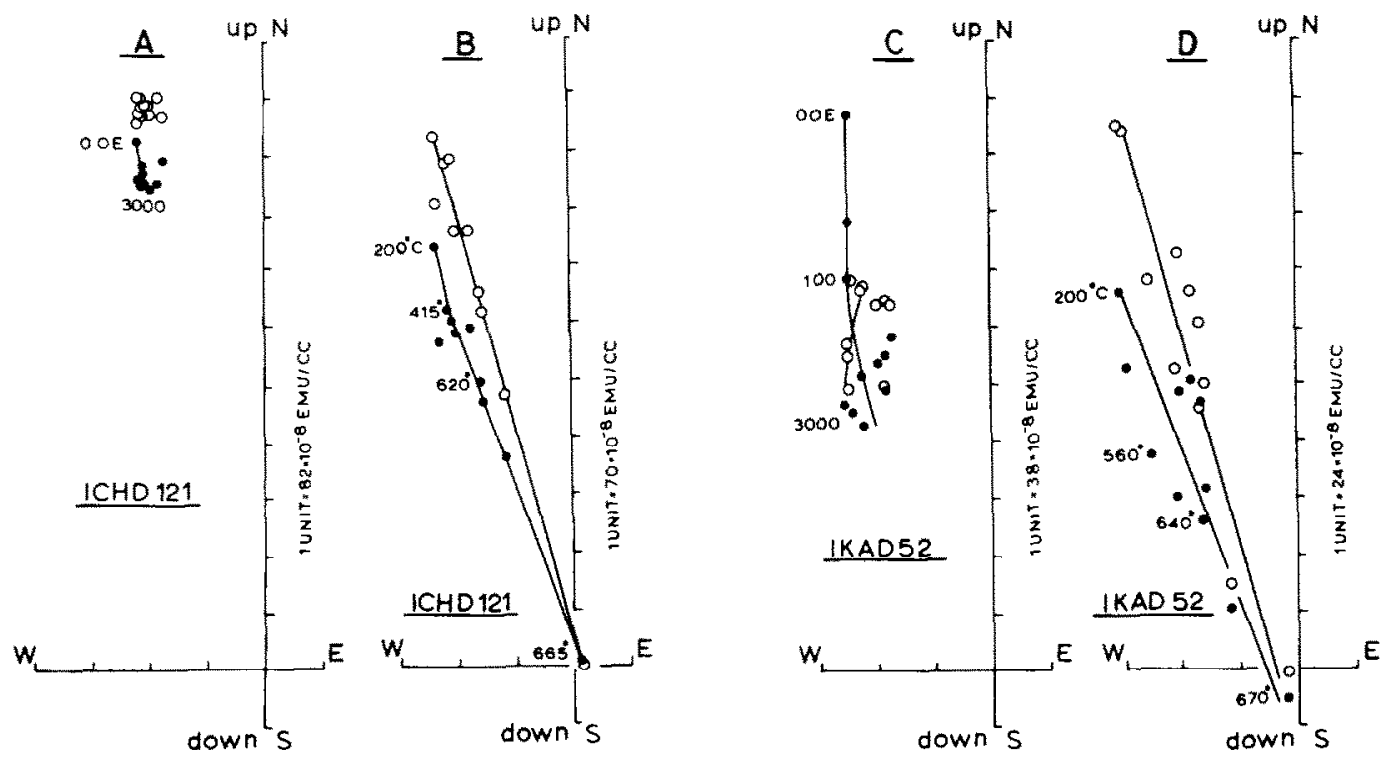

Fig. 8. Demagnetization diagrams of Chanda (A, B) and Silewara (C, D) specimens, treated with alternating fields $(A, C)$ or by thermal methods $(B, D)$, respectively. See caption to Figs. 5 and 7. 

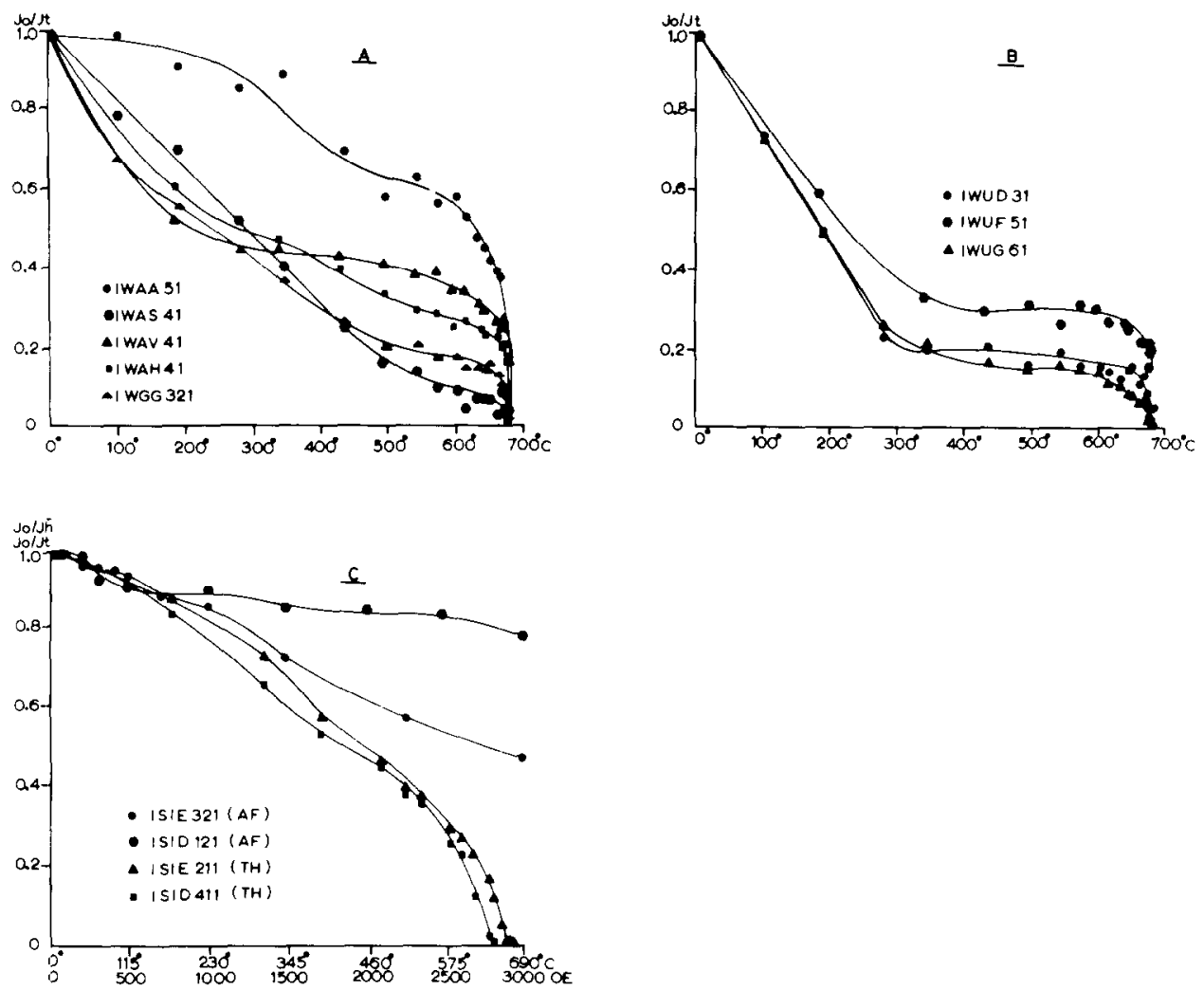

Fig. 9. Normalized intensity decay curves of the remanent magnetization during thermal cleaning (A, B, C) or A.F.-treatment (C). A. Wagdara quarry specimens. B. Balar Hill specimens. C. Sirpur specimens.

during partial progressive demagnetization between $550^{\circ}$ and $680^{\circ} \mathrm{C}$ as discussed for some Wagdara quarry samples. Therefore, the results from these sites were discarded. The mean-site direction from the 5 sites (Fig. 11) is: $D=77.3^{\circ}, I=+48^{\circ}$ (dip correction applied).

\section{Sirpur}

On a hillock near the small village of Sirpur, about $12 \mathrm{~km}$ SSE of Wun, 17 handsamples ( 4 sites) were taken from compact red shales dipping $20-25^{\circ}$ in WSW direction.

Besides some dispersed directions, the initial directions revealed a WNW and upwards directed trend (Fig. 2C). Progressive thermal treatment up to $680^{\circ} \mathrm{C}$ (Fig. 2B), revealed results which are preferable to those from A.F.-demagnetization (Fig. 7A) up to 3000 Oe peak value. Thermal demagnetization resulted in a better separation of the characteristic component, thought to be of primary 

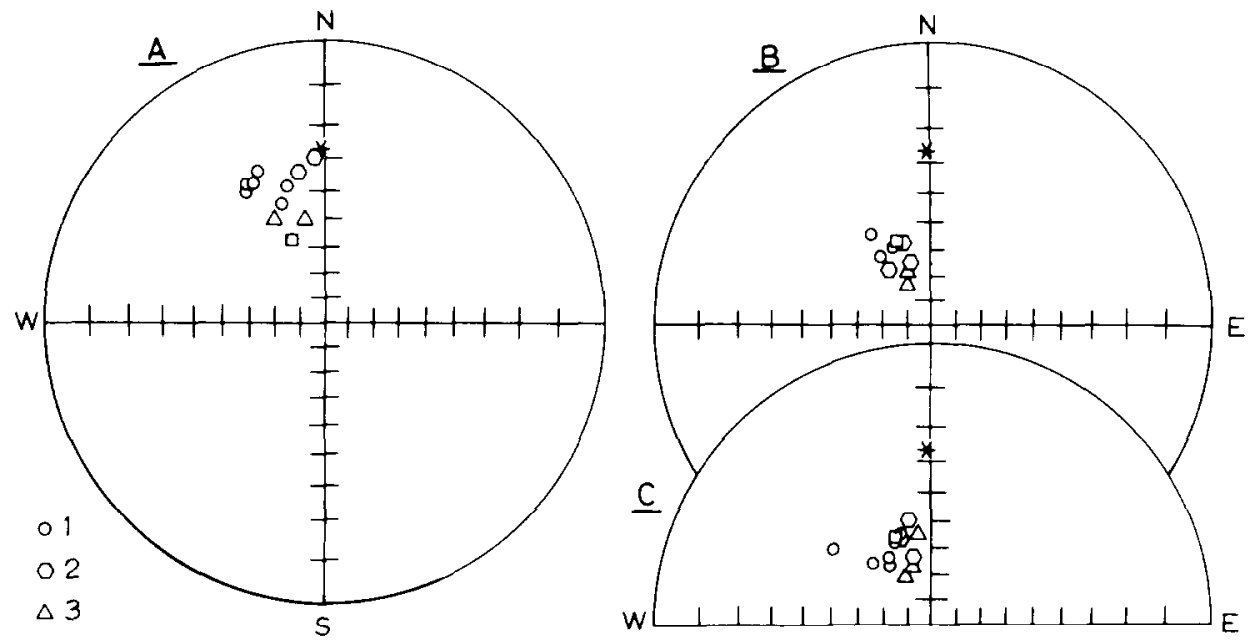

Fig. 10. Stereographic projection of secondary magnetization directions, showing Deccan Trap affinities. These directions represent magnetization components which were eliminated during thermal treatment (A, B) or by alternating fields (C). The square denotes the Lower Deccan Trap direction at the sampling locality, extrapolated according to the central axial dipole field formulae. The asterisk denotes the present local field direction at the sampling area. In Fig. $10 \mathrm{~A}, 1=$ Wagdara quarry specimens, $2=$ Balar Hill specimens, $3=$ Sirpur specimens. In Fig. $10 \mathrm{~B}$ and C, 1 = Silewara specimens, $2=$ Chanda specimens, $3=$ Taroba specimens.

origin, from a large secondary Deccan Trap component (Figs. 9C, 10A). This separation was completed at temperatures above $550^{\circ} \mathrm{C}$. Therefore, another 29 specimens were thermally demagnetized in about 11 steps between $550^{\circ}$ and $680^{\circ} \mathrm{C}$ in order to obtain directions of the characteristic component. Three sites revealed well grouped WNW-and upwards-pointing normal directions, whereas the fourth site showed both normal and reversed directions (Fig. 3C). After dip correction the mean-site direction (regardless of polarity) is: $D=129^{\circ}, I=+68.5^{\circ}, N=4$.

\section{The Silewara, ${ }^{` C h a n d a}$ and Taroba localities}

In the Silewara quarries, being the type locality of the Kamthi beds, 43 cores ( 8 sites) were drilled from rod to pale-purple compact shales dipping about $20^{\circ}$ in SSW direction.

Along the Chanda-Balharshah road, about $15 \mathrm{~km}$ south of Chanda, another 40 handsamples ( 6 sites) were taken over the total height of a $2 \mathrm{~m}$ thick purple to brick red coloured siltstone bank. The local dip of the strata was about $15^{\circ}$ in ENE direction.

Finally near Taroba, 20 cores ( 3 sites) were collected in red sandy shales, dipping $15^{\circ}$ in SSE direction.

The initial directions from the Silewara, Chanda and Taroba specimens are 
tightly grouped around the mean Deccan Trap direction (Figs. 2D, 4A), indicating the presence of a distinct Deccan Trap magnetization component in the samples. A less pronounced grouping, which is mainly formed by specimens from two Silewara sites, is directed eastwards and downwards, and shows some similarily to the reversed characteristic magnetization directions which are apparent in the specimens from the localities A, B and C. A streaking between both groupings is clearly visible (Fig. 2D).

Progressive A.F.-treatment up to 3000 Oe of 17 pilot specimens (Silewara 8 , Chanda 6 , Taroba 3) and progressive thermal treatment up to $680^{\circ}$ of 12 specimens (Silewara 4, Chanda 6 , Taroba 2), resulted in the elimination of a distinct Deccan Trap magnetization component only (Figs. 8, 10). In some specimens, also a present local field component could be eliminated during A.F.-treatment at about 800 Oe peak value. Detailed analysis by means of orthogonal projection figures of changes in the total magnetization vector upon thermal-demagnetization treatment did not establish other magnetization components, or when possibly present in some samples did not allow a reliable determination of their direction. Therefore, the collections from the Silewara, Chanda and Taroba localities were rejected for a computation of the mean Upper Permian direction from the Wardha Valley.

\section{INTERPRETATION}

The mean direction computed from the 22 accepted site-mean results (Figs. 3A, 3B, 3C, 4C, 11A; Wagdara quarry 13, Balar Hill 5, Sirpur 4), is: $D=86.5^{\circ}, I=+52^{\circ}\left(k=33.5, \alpha_{95}=5.5^{\circ}, N=3\right.$; unit weight was given to mean locality results). After dip correction this mean direction becomes: $D=101.5^{\circ}$, $I=+58.5^{\circ}\left(k=24, \alpha_{95}=6.5^{\circ}, N=3\right.$; Figs. $\left.3 \mathrm{D}, 4 \mathrm{D}, 11 \mathrm{~B}\right)$.

The consequent Late Permian pole position from the Wardha Valley specimens $\left(129^{\circ} \mathrm{E} 4^{\circ} \mathrm{N}, d p=7^{\circ}, d m=9.5^{\circ}\right)$ is in good agreement with other Indian results of Early Triassic, or probably Late Permian age, i.e. the Mangli pole (Wardha Valley, 2 sites; $124.5^{\circ} \mathrm{E} 7.5^{\circ} \mathrm{N}$; Wensink, 1968) and the Panchet pole (Damodar Valley, NE India, 1 site; $120.5^{\circ} \mathrm{E} 7.5^{\circ} \mathrm{N}$; Klootwijk, 1974a). In addition, it has to be mentioned that these three Late Permian to Early Triassic pole positions from localities on the eastern part of the Indian sulcontinent are close to a preliminary pole for the Speckled Sandstones of the Salt Range in NW Pakistan (Wensink, $1973 \mathrm{~b}$; pole at $129^{\circ} \mathrm{E} 9^{\circ} \mathrm{N}$ ). Although generally an Early Permian age has been assumed for these Speckled Sandstones, Klootwijk (1974a) has summed up alternative views for a much younger, maybe Late Permian age, for these beds.

The newly o tained Late Permian results from the Wardha Valley red beds, in accordance with the data mentioned above, indicate a counterclockwise rotation of the Indian subcontinent over about $80^{\circ}$ since Late Permian times.

The presence of hard secondary magnetization components with a normalpolarity Deccan Trap-like direction proves partial or total remagnetization of the Upper Permian red beds in the Wardha Valley during Deccan Trap times. 


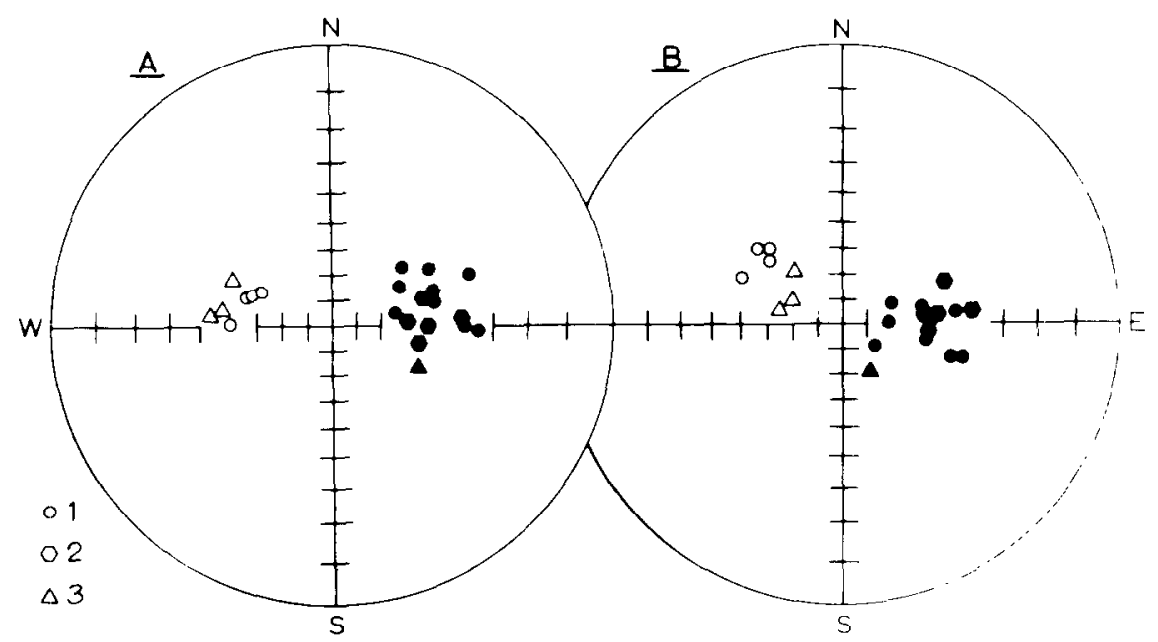

Fig. 11. Stereographic projection of site-mean results (22 sites). A. Before dip correction. B. After dip correction. 1 = Wagdara quarry sites, $2=$ Balar Hill sites, $3=$ Sirpur sites.

In the Wardha Valley localities no evidence was found for a direct baking of the sampled rocks by the formerly overlying Deccan Trap cover, although the field data indicate that, at least in some of the localities, the vertical distance to this Deccan Trap cover must have been in the order of several tens of meters.

A plausible explanation for the presence of these hard secondary Deccan Trap magnetization components in the underlying sediments might be given according to the mechanism shown by Briden (1965), Irving and Opdyke (1965) and Chamalaun (1964). Briden has indicated from experimental data that a viscous Partial Thermoremanent Magnetization (P.T.R.M.) acquired in fields of intensity comparable to the earth's magnetic field, over periods of the order of $10^{3}$ years or more and at moderate temperatures not greatly in excesses of $100^{\circ} \mathrm{C}$, would be stable for millions of years at normal temperatures. Fall in temperature and increase in grain-size have been suggested as the main causes for increase in effective relaxation time of magnetic grains and consequent stabilization of such a viscous P.T.R.M. It has been shown by Chamalaun (1964), Irving and Opdyke (1965) and Briden (1965) that removal of such secondary components in the laboratory requires far higher temperatures than their acquisition temperature and that a predominantly distributed rather than a discrete nature of the blocking temperature spectra is a specific feature of such a viscous P.T.R.M.

Because of the noticed vicinity of at least some of the Wardha Valley red bed localities to the former Deccan Trap cover, we can apply this viscous P.T.R.M. theory to explain the acquisition of the secondary Deccan Trap magnetization component. Jaeger's calculations on temperatures in the neighbourhood of cooling igneous sheets $(1957,1959)$ reveal that temperatures in the order of 
$100-200^{\circ} \mathrm{C}$ can be reached at appreciable distances from such igneous bodies. Therefore, it seems plausible that the cover of the cooling Deccan Trap flood basalts, perhaps in association with chemical effects of hydrothermal agens, caused acquisition and stabilization of a viscous P.T.R.M. component in the underlying sediments. This seems the more acceptable because this secondary Deccan Trap component is decidedly of a thermally distributed nature (Fig. 9).

According to geological data, the original extent of the Deccan Trap flood basalts lavas was much larger than their present outcrop (Wadia, 1953; Pascoe, 1963; Krishan, 1968). This might explain the findings of similar hard Deccan Trap-like secondary magnetization components in areas situated $200 \mathrm{~km}$ (Upper Vindhyan beds, Klootwijk, 1973, fig. 5) to $400 \mathrm{~km}$ (Panchet beds, Klootwijk, 1974a, fig. 7) away from the present Deccan Trap outliers (Fig. 1). It is remarkable that all secondary Deccan Trap components noticed in these studies are of normal polarity. As the basal Deccan Trap flows are expected to have had the greatest thermal and/or hydrothermal effect on the underlying sediments, some ground seems to be present to correlate these secondary magnetization components with the earlier "Pohor Normal Epoch" as postulated by Wensink (1973a). Alternatively regional upheating associated with the Deccan Trap igneous activity might have caused the remagnetization. In that case, the presence of secondary magnetization components of normal polarity would suggest that the viscous P.T.R.M. stabilized after the latest "Nipani Normal Epoch" of Deccan Trap activity. In the present case of Wardha Valley red beds, however, it seems difficult to explain the difference in effects of such a proces of regional upheating, sometimes leading to a partial or sometimes to a full remagnetization of red beds from nearby localities.

The present Late Permian results from the Wardha Valley revise preliminary results from the Kamthi beds in the Wardha Valley, reported before by Wensink (1968), and they question earlier results from Late Permian formations on the Indian subcontinent, i.e. the Kamthi beds (Godavary Valley, Verma and Bhalla, 1968) and the Hingir beds (Athavale et al., 1970). In a discussion on incompatibilities in Indian Gondwana data, Klootwijk (1974a) has already warned for the possible presence of hard younger Deccan Trap-like magnetization components in these and other Indian Gondwana red beds (some of them not studied by the author himself), which in view of the original extent of the Deccan Traps equally may have been under the influence of the Deccan Trap effusions. A probable remagnetization of some Indian Gondwana red beds has been suggested by some other authors (Verma and Narain, 1968, p. 195; Athavale and Verma, 1971, p. 311; Verma and Mital, 1974, p. 73 -- Indians themselves). Secondary Deccan Trap components presumably have been eliminated incompletely in several results of mainly Lower Gondwana age, either owing to application of the inappropriate alternating-field demagnetization technique or owing to insufficiently elaborate thermal cleaning and analysis of results. Therefore, some of these Lower Gondwana results, which represent both normal and reversed directions, are biased towards the normal Dec- 
can Trap direction. From the biased reversed directions on the one hand, an erroneously large angle of rotation has been deduced (Kamthi beds, Wensink, 1968; and possibly also the Talchir beds, Wensink and Klootwijk, 1968). The biased normal directions on the other hand have been interpreted in terms of an erroneously small angle of rotation and a too low palaeolatitude (Kamthi beds, Verma and Bhalla, 1968; Parsora beds, Bhalla and Verma, 1969; Hingir beds, Athavale et al., 1970).

POSSIBLE IMPLICATIONS FOR A TENTATIVE GONDWANALAND CONFIGURATION

From the acceptable Late Permian to Early Triassic data (i.e. the present result, the Mangli result and the Panchet result; Table III), a mean Permo-Triassic pole for the Indian subcontinent was computed $\left(125^{\circ} \mathrm{W} 6^{\circ} \mathrm{N}, \alpha_{95}=7^{\circ}\right.$, $N=3$; Fig. 12). This pole differs considerably from earlier estimates of the Indian Permo-Triassic mean pole. In order to compare this mean pole with results from other Gondwanaland continents, mean poles were computed likewise for comparable groups of data (in general of Late Permian to Triassic age), from South America and Australia. A tentative Permo-Triassic reconstruction of Gondwanaland based upon these mean poles is shown in Fig. 13B. Because of the absence of Permo-Triassic results for Africa, a Late Triassic-Jurassic mean pole was used for this continent in this reconstruction of Gondwanaland. It is known that the African pole position remained stationary during the greater part of the Mesozoic (McElhinny et al., 1968; Briden, 1970; McElhinny, 1970; McElhinny and Luck, 1970). As shown in Fig. 13B, the obtained reconstruction is in fact a cross-check to the comparable reconstruction obtain-

\section{TABLE II}

Permo-Triassic mean poles for the Gondwanaland continents

\begin{tabular}{|c|c|c|c|}
\hline Continent & Mean pole & $\alpha_{95}$ & $N$ \\
\hline South America & $69.5^{\circ} \mathrm{E} 85^{\circ} \mathrm{N}$ & $6.5^{\circ}$ & $13^{1}$ \\
\hline Africa & $99^{\circ} \mathrm{W} 65.5^{\circ} \mathrm{N}$ & $6.5^{\circ}$ & $7^{2}$ \\
\hline India & $55^{\circ} \mathrm{W} 6^{\circ} \mathrm{S}$ & $7^{\circ}$ & $3^{3}$ \\
\hline Australia and Antarctica comb. ${ }^{5}$ & $33^{\circ} \mathrm{W} 44.5^{\circ} \mathrm{N}$ & $16.5^{n}$ & $5^{1}$ \\
\hline
\end{tabular}

${ }^{1}$ Computed from: Minor Dyke Suite results, Hargraves (1968); Permo-Triassic dolerites, Veldkamp et al., (1971); results E, G, H, I, Thompson (1972); results 1-7, table 1, Creer et al. (1970). The latter pole positions were recomputed from the original declination and inclination data.

2 Computed from results: B7, B8, B9, B10, B11, B12, B13, McElhinny et al. (1968), Briden (1970).

3 Computed from: Mangli results (Wensink 1968), Panchet results (Klootwijk 1974a), and the present result.

${ }_{5}^{4}$ Computed from results: Au 6b, 6c, 6d, 7a, 7b, McElhinny and Luck (1970).

5 The Australian mean pole is applied also to Antarctica, brought in juxta-position to Australia according to the Sproll and Dietz fit (1969). 
132

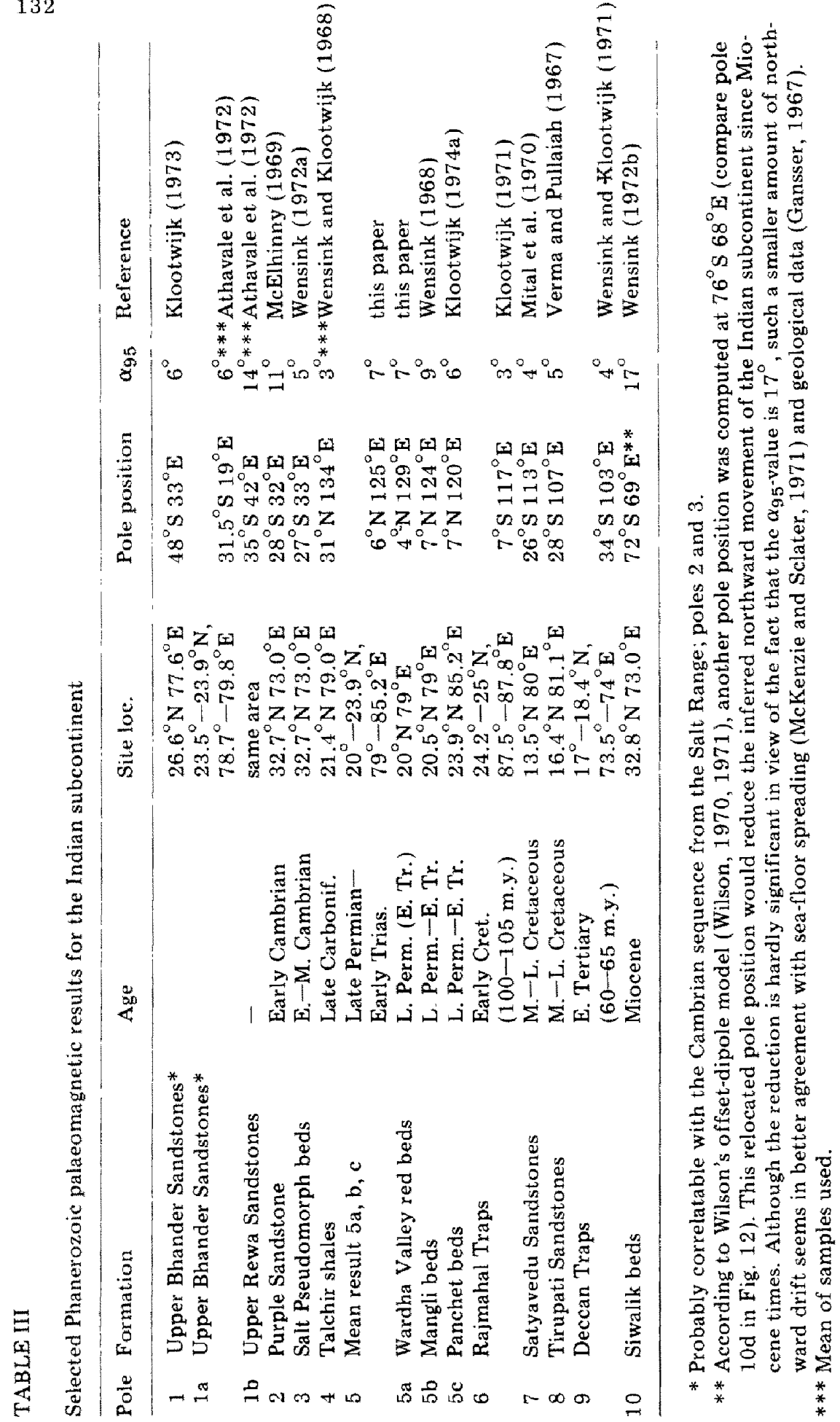




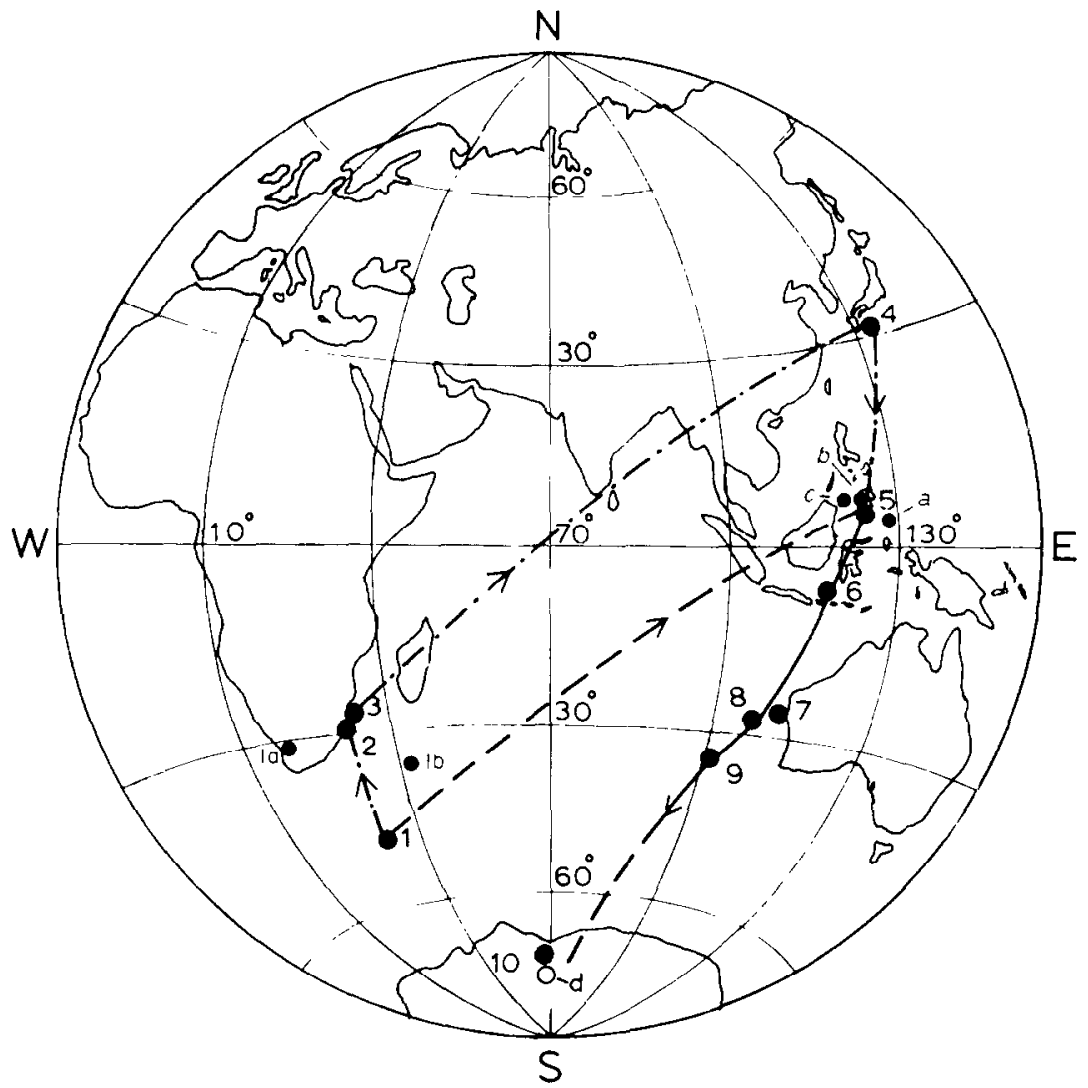

Fig. 12. Phanerozoic polar wander path for the Indian subcontinent. The poles are numbered as in Table III. For the Phanerozoic part of the polar wander curves, some possible trajectories are indicated. The well established Mesozoic-Cenozoic part is represented by the heavy line, and in addition some of the possible trajectories of the Palaeozoic part of this curve are indicated. It is clear that the Palaeozoic trajectory to a great extent depends upon acceptance (dash-dot line) or rejection (dashed line) of the Late Carboniferous result (pole 4). To a smaller extent the Palaeozoic trajectory depends upon acceptance (dashed line) or rejection (dash-dot line) of the Indus subplate hypothesis (poles $1,1 \mathrm{a}, 1 \mathrm{~b}$, 2 and 3 ), as advanced by Klootwijk (in preparation).

ed by replacing Africa in its pre-drift juxtaposition to South America (Bullard et al., 1965; Smith and Hallam, 1970) and applying the South American PermoTriassic mean pole (mean of 13 results) to the combined continents. In view of the limited number of Antarctic palaeomagnetic data, in the reconstruction Antarctica was considered to be adjacent to Australia, according to the Sproll and Dietz fit (1969).

This tentative Permo-Triassic reconstruction can be compared with an earlier obtained tentative Cambrian reconstruction (Klootwijk, 1973; present paper, Fig. 13A). Such a comparison reveals that the Permo-Triassic position of the Indian subcontinent with respect to Africa, lies farther "southwards" 

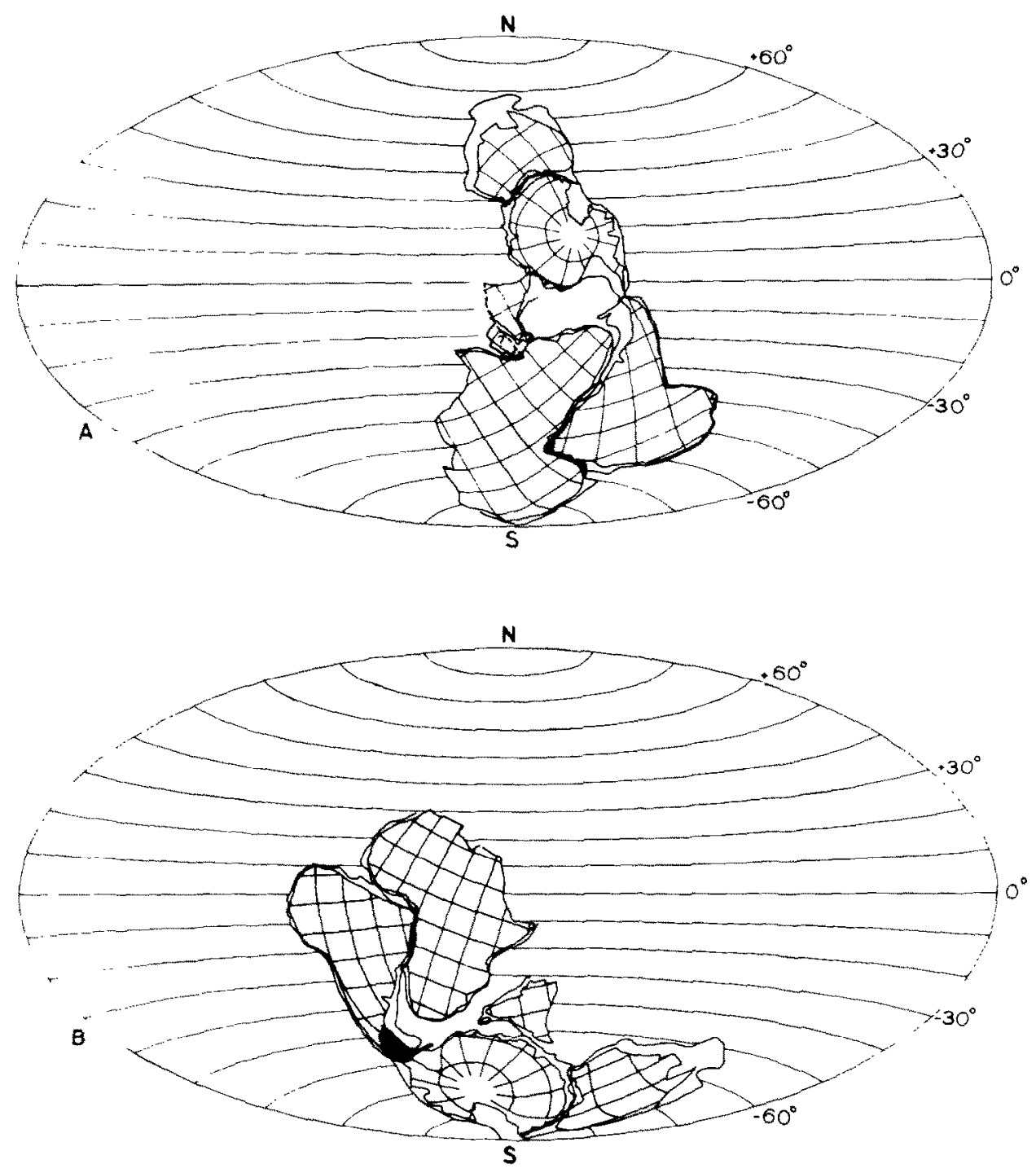

Fig. 13. Some Gondwana reconstructions in Aitoff projection, as deduced from palaeomagnetic data alone. The orientation and latitudinal positions of the continents were determined from palaeomagnetic data directly, but appropriate relative longitudinal positions of the continents were obtained by visual inspection. A. Tentative Cambrian reconstruction, see Klootwijk (1973). The NW. part of the Indian subcontinent is considered as a separate "Indus subplate" (Klootwijk, 1973). The Cambrian Salt Range data (Table III, nos. 2 and 3) are applied to this subplate only, whereas the Upper Bhander Sandstone result (Central India, Table III no. 11) is applied to the Indian subcontinent s.s. B. Permo-Triassic reconstruction, according to the mean poles denoted in Table II. Gondwanaland crossed the South pole during the Palaeozoic, thus continuing subsequently its southward movement into a northward movement at the other side of the pole. 
than its Cambrian position. This difference is considered to be real as all palaeomagnetic data used for these reconstructions satisfy modern standards of reliability. Therefore, this difference might be explained by assuming a rearrangement of the Indian and the African continents during the Palaeozoic polar crossing-and subsequently counterclockwise rotational movement of Gondwanaland, with the Indian subcontinent probably lagging somewhat behind with respect to Africa. Such an early fragmentational movement seems acceptable because slight rearrangements, close to the Palaeozoic--Mesozoic boundary, have already been suggested by Briden (1970), Athavale et al. (1970), Creer (1970), Embleton (1970) and McElhinny (1970). Moreover, Van der Voo and French (1974) have suggested a movement of Gondwanaland relative to Eurasia in that time.

Geological data seem to support such an early movement between India and Africa. Kent (1972) and Kent et al. (1971) have recently detailed the geological evidence for Permian tensional conditions in the East African marginal area and the thick Triassic halite deposits in coastal Tanzania by suggesting that the African East Coast originated long before its generally postulated Jurassic-Cretaceous development.

\section{ACKNOWLEDGEMENTS}

Dr. J.D.A. Zijderveld and Prof. J. Veldkamp kindly read and criticized the manuscript.

Thanks are due to Dr. H. Wensink who directed the author in the field.

Also thanks are due to members of the Geological Survey of India, especially Dr. P.K. Ghosh and Dr. P.K. Dutta, for helpful discussions and guidance in the field.

Dr. R.L. Wilson kindly provided a copy of a computer program for relocation of pole positions according to the off-set dipole hypothesis.

Critical suggestions by the referees for improvement of the paper are kindly acknowledged.

This study has been supported by the Netherlands Organization for the Advancement of Pure Research (Z.W.O.).

\section{REFERENCES}

Athavale, R.N. and Verma, R.K., 1970. Palaeomagnetic results on Gondwana dykes from the Damodar Valley coalfields and their bearing on the sequence of Mesozoic igneous activity in India. Geophys. J., 20: 303-316.

Athavale, R.N., Verma, R.K., Bhalla, M.S. and Pullaiah, C., 1970. Drift of the Indian subcontinent since Precambrian times. In: S.K. Runcorn (Editor), Palaeogeophysics. Academic Press, London, pp. 291-305.

Athavale, R.N., Asha, H. and Verma, R.K., 1972. Palaeomagnetism and age of Bhander and Rewa sandstones from India. Geophys. J., 28:499--509.

Bhalla, M.S. and Verma, R.K., 1969. Palaeomagnetism of Triassic Parsora sandstones from India. Phys. Earth Planet. Inter., 2: 138-146. 
Briden, J.C., 1965. Ancient secondary magnetizations in rocks. J. Geophys. Res., 70 : $5205-5221$.

Briden, J.C., 1970. Palaeomagnetic polar wandering curve for Africa. In: S.K. Runcorn (Editor), Palaeogeophysics. Academic Press, London, pp. 277-289.

Bullard, E.C., Everett, J.E. and Smith, A.G., 1965. The fit of the continents around the Atlantic. Philos. Trans. R. Soc. London, Ser. A., 258: 41-51.

Chamalaun, F.H., 1964. Origin of the secondary magnetization of the Old Red Sandstones of the Anglo-Welsh Cuvette. J. Geophys. Res., 69: 4327-4337.

Creer, K.M., 1970. A review of Palaeomagnetism. Earth Sci. Rev., 6: 369-466.

Creer, K.M., Embleton, B.J.J. and Valencio, D.A., 1970. Triassic and Permo-Triassic palaeomagnetic data for S. America. Earth Planet. Sci. Lett., 8: 173-178.

Embleton, B.J.J., 1970. Palaeomagnetic results for the Permian of South America and a comparison with the African and Australian data. Geophys. J., 21: 105-118.

Gansser, A., 1967. The Indian Ocean and the Himalayas. A geological interpretation. Eclogae Geol. Helv., 59:831-848.

Hargraves, R.B., 1968. Palaeomagnetism of the Roraima dolerites. Geophys. J., 16: 147-160.

Hughes, T.W.H., 1877. The Wardha Valley Coalfields. Mem. Geol. Surv. India, 13 (1): 115 pp.

Irving, E. and Opdyke, N.D., 1965. The palaeomagnetism of the Bloomsburg red beds and its possible applications to the tectonic history of the Appalachians. Geophys. J., 9 : $153-167$.

Jaeger, J.C., 1957. The temperature in the neighbourhood of a cooling intrusive sheet. Am. J. Sci., 255: 306-318.

Jaeger, J.C., 1959. Temperatures outside a cooling intrusive sheet. Am. J. Sci., 257: 44-54.

Kaneoka, I. and Haramura, H., 1973. K/Ar ages of successive lava flows from the Deccan Traps, India. Earth Planet. Sci. Lett., 18: 229-236.

Kent, P.E., 1972. Mesozoic history of the East Coast of Africa. Nature, 238: 147-148.

Kent, P.E., Hunt, J.A. and Johnstune, D.W., 1971. The geology and geophysics of coastal Tanzania. Inst. Geol. Sci., Geophys. Pap., 6: 101 pp.

Klootwijk, C.T., 1971. Palaeomagnetism of the - Upper Gondwana - Rajmahal Traps, NE. India. Tectonophysics, 12:149-167.

Klootwijk, C.T., 1973. Palaeomagnetism of Upper Bhander Sandstones from Central India and implications on a tentative Cambrian Gondwanaland reconstruction. Tectonophysics, 18: 123-145.

Klootwijk, C.T., 1974a. Palaeomagnetic results from some Panchet clay beds, Karanpura coalfield, Northeastern India. Tectonophysics, 21: 79-92.

Klootwijk, C.T., 1974b. Palaeomagnetism of Indian rocks and implications for the drift of the Indian part of Gondwanaland. Thesis, State University of Utrecht.

Klootwijk, C.T., in preparation. The NW part of the Indian subcontinent, an Indus subplate?

Krishnan, M.S., 1968. Geology of India and Burma. Higginbothams, Madras, 5th ed., $289 \mathrm{pp}$.

McDougall, I. and McElhinny, M.W., 1970. The Rajmahal Traps of India. K/Ar ages and Palaeomagnetism. Earth Planet. Sci. Lett., 9: 371-378.

McElhinny, M.W., 1969. Palaeomagnetism of the Cambrian Purple Sandstone from the Salt Range, West Pakistan. Earth Planet. Sci. Lett., 8: 149-205.

McElhinny, M.W., 1970. Formation of the Indian Ocean. Nature, 228: 977-979.

McElhinny, M.W. and Luck, G.R., 1970. The palaeomagnetism of the Antrim Plateau volcanics of Northern Australia. Geophys. J., 20: 191-205.

McElhinny, M.W., Briden, J.C., Jones, D.L. and Brock, A., 1968. Geological and geophysical implications of palaeomagnetic results from Africa. Rev. Geophys., 6: 201-238.

McKenzie, D. and Sclater, J.G., 1971. The evolution of the Indian Ocean since the Late Cretaceous. Geophys. J., 25: 437-528.

Mital, G.S., Verma, R.K. and Pullaiah, G., 1970. Palaeomagnetic study of Satyavedu Sandstones of Cretaceous age from Andhra Pradesh, India. Pure Appl. Geophys., 81: 177-191. 
Mulder, F.G., 1971. Palaeomagnetic research in some parts of central and southern Sweden. Sver. Geol. Unders., Arsbok, Ser. C: Avh, Och Uppsatser, 655: 56 pp.

Pal, P.C. and Bhimasankaram, V.L.S., 1973. Palaeomagnetism and the Deccan Trap volcanism. Bull. Volcanol., 35 (3): 766-789.

Pascoe, E.H., 1959. A Manual of the Geology of India and Burma, 2. Government Press, Delhi, pp. 485-1342.

Pascoe, E.H., 1963. A Manual of the Geology of India and Burma, 3. Government Press, Delhi, pp. 1343-2129.

Smith, A.G. and Hallam, A.H., 1970. The fit of the southern continents. Nature, 225: 139144.

Sproll, W.P. and Dietz, R.S., 1969. Morphological continental drift fit of Australia and Antarctica. Nature, 222: 345-348.

Thompson, R., 1972. Palaeomagnetic results from the Paganzo Basin of North-West Argentina. Earth Planet. Sci. Lett., 15: 145-156.

Van der Voo, R. and French, R.B., 1974. Apparent polar wandering for the Atlantic bordering continents. Late Carboniferous to Eocene. Earth Sci. Rev., 10: 99-119.

Veldkamp, J., Mulder, F.G. and Zijderveld, J.D.A., 1971. Palaeomagnetism of Suriname dolerites. Phys. Earth Planet. Inter., 4: 370-380.

Verma, R.K. and Bhalla, M.S., 1968. Palaeomagnetism of Kamthi sandstones of Upper Permian age from Godavary Valley. J. Geophys. Res., 73: 703-709.

Verma, R.K. and Mital, S.G., 1974. Palaeomagnetic study of a vertical sequence of Traps from Mount Pavagarh, Gujrat, India. Phys. Earth Planet. Inter., 8: 63-74.

Verma, R.K. and Narain, H., 1968. Palaeomagnetic studies of Indian rucks and continental drift. In: The Crust and Upper Mantle of the Pacific area. A.G.U., pp. 189-197.

Verma, R.K. and Pullaiah, G., 1967. Palaeomagnetism of Tirupati Sandstones from Godavary Valley, India. J. Geophys. Res., 73: 703-709.

Vilas, J.F. and Valencio, D.A., 1970. Palaeogeographic reconstructions of the Gondwanic continents based on palaeomagnetic and sea-floor spreading data. Earth Planet. Sci. Lett., $7: 397-405$.

Wadia, D.N., 1953. Geology of India. Macmillan, London. 3rd ed., 532 pp.

Wellmann, P. and McElhinny, M.W., 1970. K/Ar age of the Deccan Traps, India. Nature, 227: 595-596.

Wensink, H., 1968. Palaeomagnetism of some Gondwana red beds from Central India. Palaeogeogr. Palaeoclimat. Palaeoecol., 5: 323-343.

Wensink, H., 1972a. The palaeomagnetism of the Salt Pseudomorph beds of Middle Cambrian age from the Salt Range, West Pakistan. Earth Planet. Sci. Lett., 16: 189-194.

Wensink, H., 1972b. A note on the Palaeomagnetism of the Lower Siwaliks near Choa Saiden Shah, Potwar Plateau, West Pakistan. Pakistan J. Sci. Ind. Kes., 15: 89-91.

Wensink, H., 1973a. Newer palaeomagnetic results of the Deccan Traps, India. Tectonophysics, 17: 41-59.

Wensink, H., 1973b. The India-Pakistan subcontinent and the Gondwana reconstructions based on Palaeomagnetic results. In: D.H. Tarling and S.K. Runcorn (Editors), Implications of Continental Drift to the Earth Sciences, 1. Academic Press, London, pp. 103-116.

Wensink, H. and Klootwijk, C.T., 1968. The Palaeomagnetism of the Talchir Series of the Lower Gondwana System, Central India. Earth Planet. Sci. Lett., 4: 191-196.

Wensink, H. and Klootwijk, C.T., 1971. Palaeomagnetism of the Deccan Traps in the Western Ghats near Poona (India). Tectonophysics, 11:175-190.

Wilson, R.L., 1970. Permanent aspects of the earth's non-dipole magnetic field over Upper Tertiary times. Geophys. J., 19: 417-437.

Wilson, R.L., 1971. Dipole offset; the time-average palaeomagnetic field over the past 25 million years. Geophys. J., 22: 491-504.

Zijderveld, J.D.A., 1967. AC-demagnetization of rocks. Analysis of results. In: D.W. Collinson, K.M. Creer and S.K. Runcorn (Editors), Methods in Palaeomagnetism. Elsevier, Amsterdam, pp. 254-286. 